\title{
Identifikasi struktur dan ornamen bangunan masjid tradisional Tuha Ulee Kareng Aceh sebagai kearifan lokal
}

\author{
Zya Dyena Meutia \\ Universitas Islam Negeri Ar-Raniry, Banda Aceh, Indonesia. zya.meutia@ar-raniry.ac.id \\ Zardan Araby \\ Universitas Syiah Kuala, Banda Aceh, Indonesia. zardan_araby@yahoo.com
}

\begin{abstract}
Abstrak
Masjid Tuha Ulee Kareng adalah salah satu masjid tradisional tertua di Aceh yang masih difungsikan hingga saat ini. Namun bangunan ini masih menyimpan berbagai permasalahan diantaranya adalah fungsi bangunan yang tidak berfungsi maksimal, tidak terawatnya struktur dan material bangunan, serta kurangnya pengetahuan masyarakat tentang keberadaan arsitektur masjid ini. Penelitian ini bertujuan untuk mengidentifikasi unsur kearifan lokal pada bangunan masjid Tuha Ulee Kareng, terutama pada komponen struktur dan ornamennya yang telah menjadi ciri khas Aceh di masa lampau. Pengumpulan data dilakukan dengan melakukan observasi lapangan dan wawancara semi-terstruktur terhadap 15 informan kunci. Hasil penelusuran menunjukkan keunikan masjid terlihat pada bagian atap yang memiliki dua tingkatan. Struktur dan konstruksi bangunan masjid masih dalam kondisi asli dengan bahan material kayu. Berbagai ukiran ornamen yang menghiasi kontruksi kayu tidak hanya sebagai perwujudan ekspresi seni, namun menyiratkan makna hubungan manusia dengan Tuhan penciptanya. Hal tersebut diterjemahkan sebagai bentuk kearifan lokal pada bangunan Masjid Tuha Ulee Kareng
\end{abstract}

Kata kunci: masjid Tuha Ulee Kareng, kearifan lokal, struktur, ornamen

\begin{abstract}
The Ulee Kareng Tuha mosque is one of the oldest traditional mosques in Aceh, which is still functioning today. However, this building still has various problems, including impaired function, low maintenance of the structure and building materials, and the lack of public knowledge about this mosque's existence. This study aims to identify local wisdom elements in the Ulee Kareng Tuha mosque, especially in the structural components and ornaments that have characterized Aceh in the past. Data collection was carried out by conducting field observations and semi-structured interviews with 15 key informants. The search results show that the mosque's uniqueness can be seen on the roof, which has two levels. The structure and construction of the mosque building are still in original condition with wood materials. Various ornamental carvings that adorn wooden constructions are the embodiment of artistic expression and imply man's relationship with God as the creator. That expression was translated as a form of local wisdom to the Ulee Kareng Tuha mosque building.
\end{abstract}

Keywords: Ulee Kareng Tuha mosque, local wisdom, structure, ornaments

Received: 2020-02-03 | Accepted: 2020-05-30 | DOI: 10.29080/eija.v6i1.806 | Page: 33 - 41

EMARA: Indonesian Journal of Architecture

http://jurnalsaintek.uinsby.ac.id/index.php/EIJA

This article is open access distributed under the terms of the Creative Commons Attribution ShareAlike 4.0 International License, which permits unrestricted use, distribution, and reproduction in any medium provided the original work is properly cited. 


\section{Pendahuluan}

Kearifan lokal merupakan pengetahuan dasar yang diperoleh dari gaya hidup yang seimbang dengan alam. Ini terkait dengan budaya dalam masyarakat yang terakumulasi dan diwariskan turun temurun (Mungmachon, 2012). Dalam arsitektur, kearifan lokal bekerja pada banyak bagian seperti fasad, struktur, dan ornamen yang lahir dari nilai kekhasan (Sari, 2009). Di Aceh, kearifan lokal sendiri telah terbalut nilai ajaran Islam. Sebagai agama mayoritas. Namun, Islam sendiri menghargai keaslian yang sudah ada lebih dulu kehadirannya; oleh karena itu, fungsifungsi Islam diadopsi secara harmonis dalam karakter kekhasannya (Omar \& AlQudsy, 2019).

Masjid menjadi wujud kearifan lokal yang esensial bagi umat muslim di dunia karena fungsinya sebagai tempat melaksanakan ibadah kepada Allah SWT. Setiap masjid tentunya memiliki gaya arsitektur tersendiri yang menampilkan ciri khas masing-masing, baik dari perspektif budaya, sosial, politik maupun sisi spiritualnya. Setiap masjid akan menunjukkan ekspresi dari gaya arsitektur yang diterapkan pada struktur, komponen, fasad, interior dan eksterior dari bangunan masjid tersebut (Fanani, 2009; Sari et al., 2020).

Salah satu permasalahan yang ditemukan terkait keberadaan masjid tua adalah banyaknya masjid tua peninggalan sejarah yang terabaikan keberadaannya serta kurang terpelihara dengan baik kondisi fisiknya. Padahal masjid tua mengandung banyak pembelajaran, khususnya di bidang arsitektur dengan melakukan kajian terhadap teknologi struktur dan komponen ornamen dengan berbagai makna yang tersirat dari arsitektur masjid-masjid tua tersebut (Susanta et al., 2007).
Masjid Tuha Ulee Kareng merupakan salah satu masjid tertua yang terdapat di wilayah Aceh. Akan tetapi keberadaannya masih kurang populer di kalangan masyarakat Aceh sendiri dan kalah populer dengan masjid-masjid tua lainnya di Aceh, seperti masjid Tuha Indrapuri yang lebih banyak dikenal oleh masyarakat luas. Ketidaktahuan masyarat menjadi hal yang sangat disayangkan mengingat kondisi struktur dan ornamen khas pada bangunan Masjid Tuha Ulee Kareng telah banyak mengalami kerusakan. Penelitian terkait adaptasi kearifan lokal pada disain masjid di Aceh pun baru dilakukan pada objek masjid Indrapura di Aceh Besar dan Masjid Tengku Dipucok Krueng di Pidie Jaya (Sari et al., 2020).

Berbagai penelitian sebelumnya belum ada yang membahas tentang kearifan lokal dari perspektif ilmu arsitektur, khususnya kajian tentang struktur kayu dan ornamen khas dari bangunan ini. Selama ini penelitian terkait masjid Tuha Ulee Kareng difokuskan pada konsep mudharabah (Nindayani, 2018) serta keberadaan lembaga adat gampong di masjid Tuha Ulee Kareng (Harist, 2018). Sampai saat ini belum ada penelitian tersendiri terkait arsitektur masjid Tuha Ulee Kareng.

Kelestarian Masjid Tuha Ulee Kareng dengan nilai sejarah dan keunikan komponen struktur konstruksi serta ornamennya haruslah menjadi perhatian. Hal ini pun sejalan langkah Tim Registrasi Cagar Budaya (TRCB) Kota Banda Aceh yang mengusulkan masjid Tuha Ulee Kareng sebagai salah satu bangunan cagar budaya (Nurdin, 2020). Selain itu kajian dari berbagai disiplin keilmuan terhadap keberadaan masjid Tuha Ulee Kareng perlu terus dilakukan. Penelitian ini bertujuan untuk mengidentifikasi unsur 
kearifan lokal pada bangunan masjid Tuha Ulee Kareng, terutama pada komponen struktur dan ornamennya yang telah menjadi ciri khas Aceh di masa lampau. Hasil kajian diharapkan dapat memperkaya khasanah dan wawasan masyarakat terhadap keberadaan masjid Tuha Ulee Kareng.

\section{Metode}

Penelitian ini menggunakan pendekatan kualitatif dengan menjaring pendapat dari informan purposif, yang diberikan pertanyaan terbuka terkait identifikasi kearifan lokal pada Masjid tradisional Tuha Ulee Kareng. Informan purposif sendiri merupakan informan yang dipilih dengan latar belakang tertentu (Creswell, 2014), dalam hal ini latar belakang pendidikan arsitektur, tokoh agama ataupun tokoh masyarakat yang mengetahui sejarah masjid Tuha Ulee Kareng. Data dikumpulkan dengan metode observasi lapangan dan wawancara semi terstruktur kepada 15 orang informan untuk mengetahui identitas kearifan lokal pada bangunan masjid Tuha Ulee Kareng. Jawaban dari informan yang berupa data tekstual (text data) akan diolah melalui tahapan pengkodean data (coding data). Hasil coding data kemudian akan dikelompokkan menjadi berbagai katagori yang memunculkan sejumlah tema yang lebih spesifik dan berhubungan satu sama lain (Creswell, 2014). Hasil analisis akan menghasilkan seperangkat kerangka komponen penilaian yang diharapkan akan menjadi landasan penelitian selanjutnya.

\section{Hasil dan Pembahasan \\ Identifikasi kata kunci}

Sejumlah kata kunci diidentifikasi berdasarkan hasil wawancara dengan para informan kunci. Berikut beberapa pernyataan para informan terkait eksistensi masjid Tuha Ulee Kareng serta berfokus kepada komponen struktur dan ornamen dari masjid itu sendiri.

"Arsitektur masjid Tuha Ulee Kareng menunjukkan gaya arsitektur yang dibangun berdasarkan tradisi seni bangunan lama" (Musaidi, Penjaga, 50 tahun)

"Ornamen yang diterapkan pada balokbalok penyangga adalah motif ukiran flora dan kaligafi, Pahatan kaligrafi pada balokbalok kayu tersebut berisi do'a qunut, Ormamen pada balok - balok penyangga menunjukkan ciri arabesque yang dibuat dari bentuk geometris berisi motif suluran" (Al-Yasa'Abu Bakar, Dosen, 65 tahun).

"Keunikan masjid Tuha Ulee Kareng terlihat pada ornamen ukiran yang memenuhi seluruh balok penyangga tiang dan atap serta balok gantung berbentuk jantung pisang yang terletak di tengahtengah puncak atap paling atas" (Raidi, Guru, 45 tahun).

"Masjid Tuha Ulee Kareng adalah masjid kuno, bersejarah peninggalan Islam dan tempat musyawarah warga setempat" (Wak Kolak, warga setempat, 41 tahun).

Berdasarkan jawaban dari ke 15 informan, diperoleh hasil analisis data teks yang dapat dilihat pada Tabel 1 .

Tabel 1. Kata kunci penting dalam mengidentifikasi kearifan lokal masjid Tuha Ulee Kareng

\begin{tabular}{clc}
\hline No & Kata kunci penting & $\%$ \\
\hline 1 & Keaslian material & 25 \\
2 & Kaligrafi & 7 \\
3 & Struktur dan material kayu & 25 \\
4 & Ornamen khas Aceh & 5 \\
5 & Pelestarian bangunan & 8 \\
6 & Atap limas & 12 \\
7 & Arsitektur Islam & 8 \\
8 & Masjid kuno/tradisional & 10 \\
\hline
\end{tabular}

Sumber: hasil analisis (2019)

\section{Arsitektur masjid Tuha Ulee Kareng}

Masjid ini pernah menjadi pusat pembelajaran agama Islam di Kutaraja pada abad-18 (Barliana, 2008). Banyak tamu atau pengunjung yang datang dari berbagai negara, seperti Arab, Turki dan Malaysia untuk mempelajari berbagai pengetahuan tentang Islam. Masjid yang 
berdiri di tahun 1826 Masehi ini memiliki beberapa bagian arsitektur unik yang penuh makna. Seolah-olah masjid tersebut tidak sekedar dibangun, tapi seakan juga sedang menyiarkan ajaran Tauhid kepada para pengunjungnya.

Masjid Tuha Ulee Kareng yang berdiri diatas sepetak lahan memiliki banyak nilai arsitektur Islami yang terkandung pada berbagai bagian masjid. Pembangunan yang penuh nilai filosofis terlihat jelas pada setiap bagian bangunan masjid. Sampai saat ini masjid Tuha Ulee Kareng belum mengalami perubahan yang signifikan. Bentuk awalnya masih dipertahankan dengan hanya beberapa tambahan, seperti pada bagian atap (bubong), jerjak kayu pada jendela, lantai keramik dan dinding beton semi permanen.

Arsitektur masjid Tuha Ulee Kareng menunjukkan gaya arsitektur yang dibangun berdasarkan tradisi seni bangunan lama. Atap pada masjid ini merupakan adaptasi bentuk dari atap rumah Aceh. Konstruksi atap dibuat bersusun yang dikenal juga dengan sebutan atap tumpang. Namun jika masjidmasjid kuno yang umum dijumpai di Indonesia memiliki atap tumpang tiga, maka masjid Tuha Ulee Kareng hanya memiliki tumpang dua. Hal ini lebih disebabkan dari ukuran masjid Tuha Ulee Kareng yang tidak terlalu besar.

Pembuatan jumlah tumpang dua menyesuaikan dengan ukuran bangunan, sehingga bentuknya akan simetris dan tetap terlihat estetis. Selain itu, dengan ukuran bangunan yang tidak terlalu besar, penggunaan atap tumpang bersusun dua merupakan suatu keharusan. Hal tersebut dimaksudkan agar struktur bagian tengah dan bawah masjid tidak menanggung beban atap yang terlalu berat, sehingga akan mempengaruhi kestabilan bangunan (BPCB Aceh, 2017). Pada bagian balok dan rangka kuda-kuda masjid terdapat ukiran kaligrafi yang memperindah tampilan masjid. Pada material konstruksi kayu yang digunakan terdapat ornamen ukiran kaligrafi yang masih asli dan belum mengalami perubahan (Gambar 1).

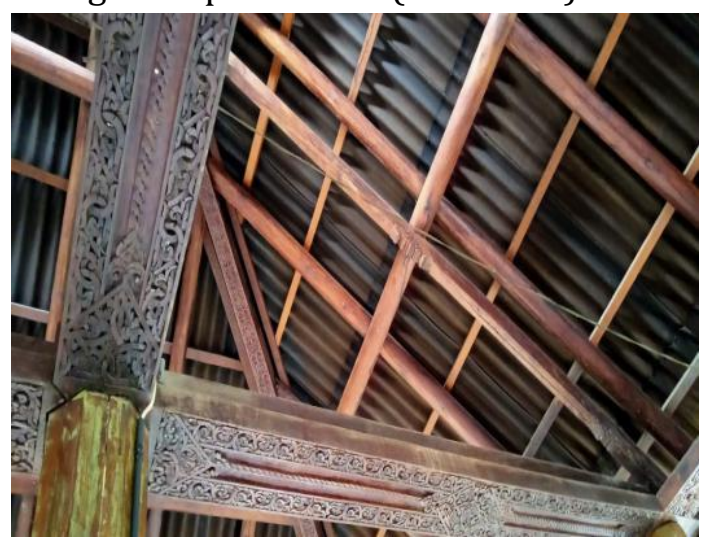

Gambar 1. Pola geometri terpahat bagian papan balok (Sumber: dokumentasi peneliti, 2019)

Bentukan atap sederhana, berbentuk limas bertingkat, seolah menyampaikan tiga unsur (trilogi) ajaran Islam (Fikriarini, 2010) yaitu:

1) Islam, yang merupakan ajaran lahiriyah, seperti yang termaktub dalam rukun Islam, yaitu dua kalimat syahadat, shalat fardhu lima waktu, ibadah puasa, zakat, dan haji.

2) Iman, merupakan hal yang mencakup perkara batiniyah yang ada di dalam hati, yang termasuk ke dalam rukun Iman.

3) Ihsan, merupakan hal hal yang mencakup lahiriyah dan bathiniyah manusia terhadap Allah SWT.

Tak hanya trilogi Islam, atap masjid Tuha Ulee Kareng juga mengisyaratkan dua fase kehidupan manusia, yaitu fase lahirnya manusia ke muka bumi, fase dimana pencarian manusia akan amalan baik, yang akan dijadikan modal untuk menghadapi fase akhir, yaitu kematian. Dibagian interior masjid, akan terlihat struktur kayu yang menarik dengan bentuk bangunan simetris. Terdapat ukiran kaligrafi dan ornamen khas bermotif flora yang mencerminkan 
kesederhanaan Islam. Kemudian pola geometris yang merupakan simbol kebudayaan Islam juga terukir pada bagian kayu masjid, selain bentukan seni kaligrafi yang juga terpahat pada beberapa bagian kayu tua yang memiliki kekuatan yang sangat baik (Fanani, 2009).

\section{Struktur dan konstruksi kayu masjid Tuha Ulee Kareng}

Struktur dan konstruksi masjid Tuha Ulee Kareng secara keseluruhan terbuat dari kayu dan ditopang oleh empat buah tiang soko guru berbentuk persegi delapan. Untuk menahan beban bangunan ditambahkan tiang penampil yang disusun berbaris membentuk tiga kolom berjumlah dua belas buah. Pada bagian atas tiang-tiang tersebut diletakkan balok dalam posisi membujur dan melintang membentuk kerangka bangunan. Kerangka bangunan inilah yang menjadi titik tumpu beban bangunan serta penguat konstruksi atap (Gambar 2).

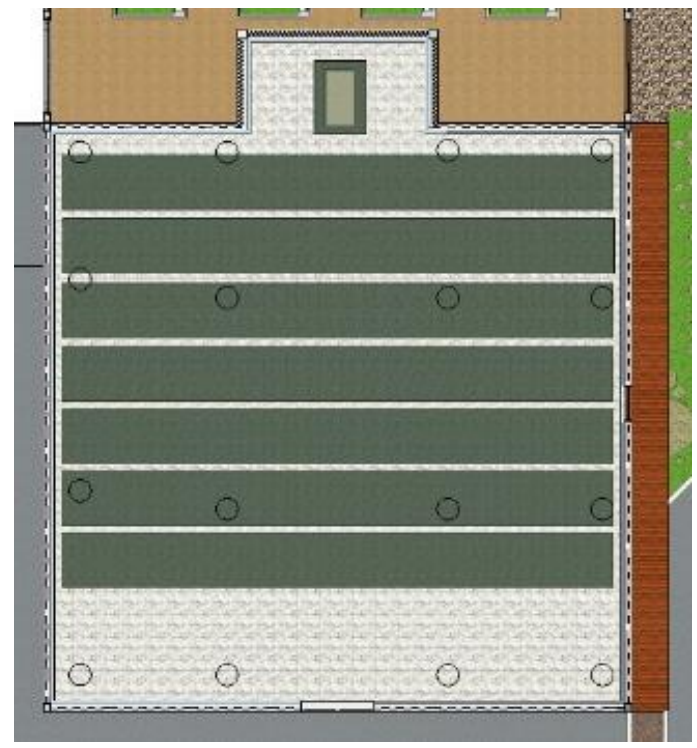

Gambar 2. Ilustrasi denah masjid Tuha Ulee Kareng (Sumber : analisis peneliti, 2019)

Konstruksi atap mulai dari tumpang pertama dan kedua disangga oleh tiang soko guru dan dikuatkan dengan tiang penampil. Pada bagian ujung tiang soko guru diletakkan papan-papan tebal yang berfungsi sebagai penghubung tiang soko guru untuk menjaga kestabilannya. Papan yang menghubungkan tiang soko guru dipenuhi dengan ornamen ukiran flora dan kaligrafi yang menunjukkan gaya arabesque, dengan motif geometris berbentuk suluras bunga yang saling bertautan. Namun tidak adanya perawatan yang memadai terhadap masjid Tuha Ulee Kareng menyebabkan kayu penyangga sudah banyak yang lapuk termakan rayap. Kondisi tersebut menyebabkan ornamen ukiran banyak yang rusak (Gambar 3)

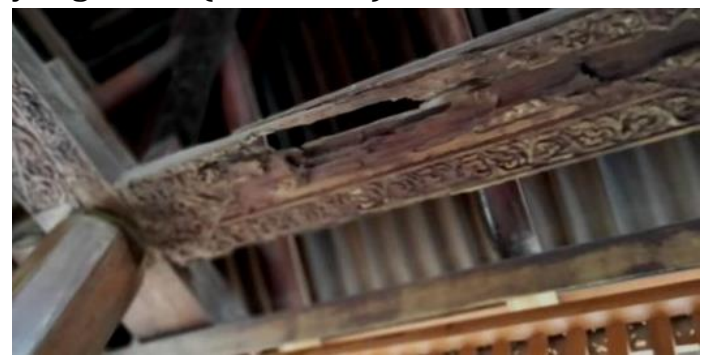

Gambar 3. Struktur kayu dan ornamen yang sudah mulai rusak dan tidak terawat (Sumber: dokumentasi peneliti, 2019)

Konstruksi dinding bangunan dikuatkan oleh tiang penampil yang sekaligus juga sebagai tempat untuk meletakkan balok-balok penyangga atap tumpang pada bagian pertama. Tiangtiang penampil ini dihubungkan dengan papan-papan tebal yang berada di bagian bawah tiang mendekati lantai sebagai pengunci tiang sehingga tiang dapat berdiri kokoh. Di ujung tiang bagian atas diletakkan papan-papan tebal yang dipenuhi dengan ukiran. Papan-papan tebal ini berfungsi sebagai penyangga konstruksi atap tumpang bagian pertama. Papan-papan tebal ini diletakkan dengan posisi melintang dan membujur.

Penguatan akhir konstruksi atap dilakukan dengan menambah tiang gantung yang terletak tepat di puncak bangunan (gambar 4). Tiang gantung berbentuk jantung pisang yang juga dipenuhi dengan ornamen ukiran. Tiang gantung ini disangga lagi dengan dengan papan-papan tebal dengan sistem pasak yakni memasukkan ujung papan yang 
telah diruncingkan ke lubang pada papan yang lain (Gambar 5). Sistem pasak ini dibuat pada seluruh konstruksi bangunan dan terbukti sistem pasak ini mampu membuat bangunan tetap stabil dan kokoh hingga sekarang walaupun dihantam guncangan hebat saat gempa bumi dan tsunami Aceh tahun 2004 (Araby et al., 2019).

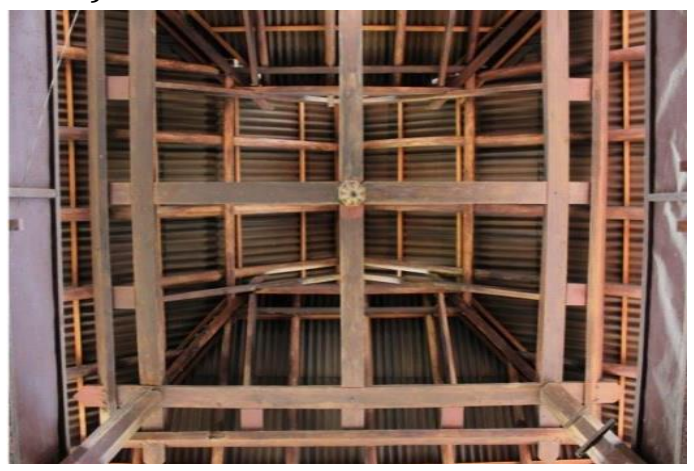

Gambar 4. Detail balok tengah sebagai penguat kontruksi bangunan (Sumber: dokumentasi peneliti, 2019)

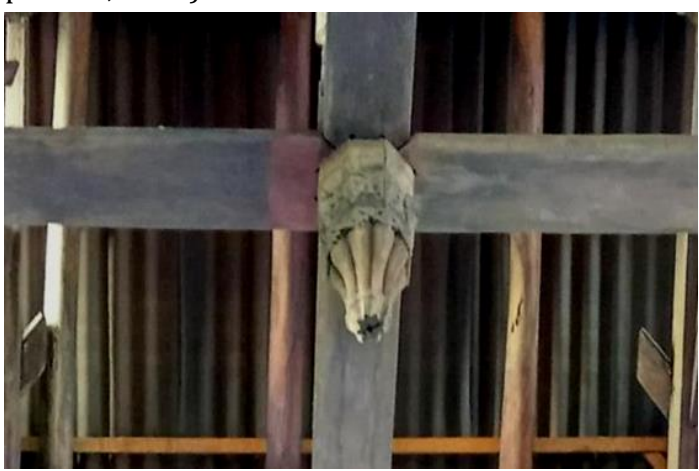

Gambar 5. Ornamen gantung pada masjid Tuha Ulee Kareng (Sumber: dokumentasi peneliti, 2019)

Konstruksi bangunan yang menggunakan atap tumpang menunjukkan adanya kesinambungan budaya dari masa pra Islam. Tidak diragukan lagi bahwa dalam masyarakat Aceh juga terjadi penyerapan budayabudaya yang berasal dari Hindu-Budha (Feener et al., 2011). Penyerapan budaya dalam masyarakat Aceh lebih kepada pengadopsian tradisi-tradisi agama sebelumnya yang diaplikasikan dalam bentuk arsitektur dan seni ukir. Saat ini atap masjid Tuha Ulee Kareng sudah diganti dengan bahan seng. Alasan terutama penggantian bahan penutup atap adalah daya tahan seng yang lebih lama dibandingkan dengan bahan penutup atap dari daun. Atap seng diletakkan pada balok-balok kayu yang berbentuk bulat yang berjumlah enam puluh buah membentuk rusuk payung terbuka. Balokbalok penahan atap seng ini tidak dipaku maupun diikat namun dimasukkan ke lubang pada bagian papan yang berukir yang terletak di sekeliling atap tumpang pertama dan kedua.

Sedangkan untuk pintu masuk masjid terletak di bagian timur. Dilihat dari bentuknya, pintu masuk merupakan tambahan dari masa kemudian. Di depan pintu masuk terdapat tangga yang berjumlah dua undakan terbuat dari semen. Adanya tangga mengindikasikan bahwa bangunan masjid Tuha Ulee Kareng dulunya adalah bangunan yang tinggi, namun karena kegiatan pembuatan dan peninggian jalan menyebabkan bangunan masjid ini sekarang menjadi hampir sama tinggi dengan jalan.

Masjid Tuha Ulee Kareng tidak memiliki jendela. Hal tersebut disebabkan masjid yang hanya memiliki dinding bangunan berukuran setengah meter. Bagian atas dinding hanya diberi penutup dari bilah-bilah kayu kecil yang memungkinkan udara dapat masuk dengan bebas ke dalam ruangan. Kemungkinan besar bilah-bilah kayu penutup ini merupakan tambahan dari masa kemudian yang dilakukan oleh masyarakat setempat. Perubahan lain juga terlihat pada bagian lantai yang sudah menggunakan lantai keramik. Penggantian bahan lantai menyebabkan aki tameh atau alas tiang menjadi tertimbun sebagian sehingga dasar kaki tiang tidak terlihat lagi.

Ornamen dan ukiran kayu masjid Tuha Ulee Kareng

Keunikan masjid Tuha Ulee Kareng terlihat pada ornamen ukiran yang 
memenuhi seluruh balok penyangga tiang dan atap. Selain itu keunikan dapat dijumpai pada balok gantung berbentuk jantung pisang yang terletak di tengahtengah puncak atap teratas. Ornamen yang diterapkan pada balok penyangga adalah motif ukiran flora dan kaligrafi. Namun kaligrafi yang dipahatkan pada balok kayu sulit untuk dibaca karena kondisinya yang sudah mulai rusak termakan rayap.

Menurut penuturan salah satu responden, Al-Yasa'Abu Bakar, pahatan kaligrafi pada balok kayu di masjid Tuha Ulee Kareng berisikan bacaan do'a Qunut. Ornamen flora yang diterapkan pada balok-balok penyangga membuktikan bahwa ekspresi seniman pahat pada masa masjid dibangun masih terpengaruh dengan inspirasi lingkungan alam. Selain itu, larangan tentang penggambaran makhluk bernyawa menuntun seniman ukir pada zaman pembangunan masjid untuk mengalihkan motif nya ke bentukbentuk flora dan geometris.

Ornamen ukiran flora dan kaligrafi yang rumit sekaligus atraktif pada masjid Tuha Ulee Kareng menjadi bukti kemahiran tukang Aceh pada masa lampau.. Ornamen flora sendiri melambangkan kesuburan dan ketenangan serta menunjukkan hubungan manusia dengan alam. Selain itu motif flora dapat memiliki arti suci, bermakna indah, berbentuk halus dan simetris, serba estetis serta menggambarkan kondisi kehidupan masyarakatnya (Bagus et al., 2019). Selain itu, pemilihan ornamen flora pada arsitektur masjid Tuha Ulee Kareng juga dipengaruhi oleh hadis Nabi yang melarang umatnya menggambarkan makhluk hidup. Larangan ini akhirnya menjadi pedoman bagi seniman muslim dalam berkreasi sehingga tidak bertentangan dengan ajaran islam.

Selain bentuk flora, seniman ukir masa lampau juga banyak menggunakan ornamen kaligrafi pada karya seninya terutama pada bidang arsitektur masjid. Pemilihan ornamen kaligrafi yang berisi ayat-ayat Al-Qur'an ataupun doa erat kaitannya dengan identitas agama seniman dan masyarakat di sekitarnya. Semangat Islam di masyarakat terutama seniman ukir pada akhirnya menuntun mereka mengembangkan seni kaligrafi Islam yang diaplikasikan pada kayu-kayu penyangga masjid Tuha Ulee Kareng (Gambar 6).

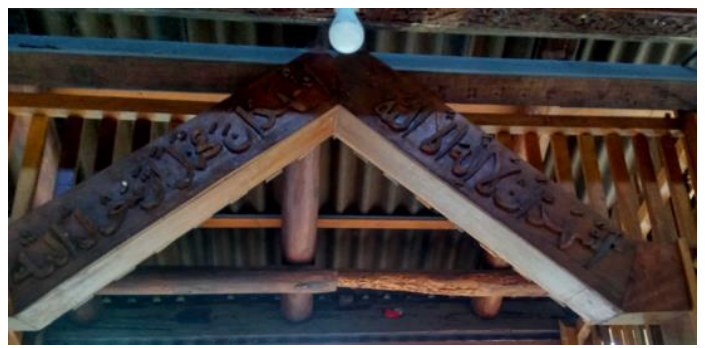

Gambar 6. Detail Ukiran Kaligrafi Pada Balok Kayu Di Masjid Tuha Ulee Kareng (Sumber: dokumentasi peneliti, 2019)

Ornamen kaligrafi dalam masyarakat Aceh sering juga disebut dengan bungong kalimah (Maulin et al., 2019). Bungong kalimah merupakan ekspresi seni yang menunjukkan hubungan manusia dengan Allah. Bungong kalimah diidentikkan dengan pesan-pesan keagamaan sekaligus sebagai jalan untuk mengingat Allah. Seniman pada masa lampau dalam menciptakan karya seninya tidak sernatamata ditujukan untuk keindahan saja namun juga sebagai ekspresi untuk mengungkapkan rasa syukur dan menjadi identitas seni Islam.

\section{Kesimpulan}

Bangunan masjid Tuha Ule Kareng merupakan saksi bisu akan sejarah perkembangan Islam di Aceh. Dalam konteks arsitektur lokal, masjid Tuha Ulee Kareng menjadi bukti ekspresi kearifan lokal dalam wujud struktur dan konstruksi kayu. Ornamen khas bermotif flora pada bagian struktur dan konstruksi masjid menyiratkan makna hubungan manusia dengan alam, sedangkan makna 
hubungan antar manusia dengan Allah SWT sebagai sang pencipta diwujudkan dalam bentuk bungong kalimah (kaligrafi). Konstruksi atap tumpang juga telah mengindikasikan adanya kesinambungan bangunan masjid Tuha Ulee Kareng dengan budaya masa pra-Islam di Aceh. Hal ini semakin menegaskan pengaruh budaya lokal memainkan peran yang penting terhadap komponen material, struktur dan konstruksi masjid Tuha Ulee Kareng.

\section{Pernyataan Penulis}

Dengan ini penulis menyatakan bahwa penelitian ini terbebas dari konflik kepentingan dengan pihak manapun

\section{Ucapan Terimakasih}

Penulis mengucapkan terimakasih kepada Universitas Islam Negeri Ar-Raniry serta semua pihak yang telah mendukung kegiatan penelitian ini.

\section{Referensi}

Araby, Z., Abdullah, \& Afiffuddin, M. (2019). Perilaku dan daktilitas perbaikan sambungan balok dan kolom beton bertulang. Prosiding Konferensi Nasional Teknik Sipil Ke13 (KoNTekS 13), 146-153.

Bagus, F., Widagdo, J., \& Arifin, Z. (2019). Bentuk rupa dan makna simbolik motif ukir pada masjid mantingan jepara dalam konteks sosial budaya. Imajinasi : Jurnal Seni, 13(2), 55-64. https://doi.org/10.15294/imajinasi .v13i2.21940

Barliana, M. S. (2008). Perkembangan arsitektur masjid: Suatu transformasi bentuk dan ruang. Historia: Jurnal Pendidik dan Peneliti Sejarah, 9(2), 45-60. https://doi.org/10.17509/historia. v9i2.12171

BPCB Aceh. (2017). Masjid-masjid kuno Aceh. Kementerian Pendidikan dan Kebudayaan Republik Indonesia.

Creswell, J. W. (2014). Research Design: Qualitative, Quantitative, and Mixed Methods Approaches (4th Edition). SAGE.
Fanani, A. (2009). Arsitektur masjid. Bentang. https://books.google.com/books/a bout/Arsitektur_masjid.html?hl=id \&id=Cs3p7ir7bk0C

Feener, R. M., Daly, P., \& Reed, A. (2011). Mapping the Acehnese Past. BRILL.

Fikriarini, A. (2010). Arsitektur islam: Seni ruang dalam peradaban islam. $E L$ HARAKAH Jurnal Budaya Islam, 12(3), 194-206. https://doi.org/10.18860/el.v0i0.4 52

Harist, M. H. (2018). Peran Lembaga Adat Gampong terhadap Mediasi Perselisihan Rumah Tangga (Studi Kasus di Gampong Pango Deah Kec. Ulee Kareng) [Skripsi, UIN Ar-Raniry Banda Aceh]. http://library.arraniry.ac.id/

Maulin, S., Zuriana, C., \& Lindawati, L. (2019). Makna motif ragam hias pada rumah tradisional Aceh di Museum Aceh. Jurnal Ilmiah Mahasiswa Pendidikan Seni, Drama, Tari \& Musik, 4(1), 78-96. http://www.jim.unsyiah.ac.id/send ratasik/article/view/13136

Mungmachon, M. R. (2012). Knowledge and Local Wisdom: Community Treasure. International Journal of Humanities and Social Science, 2(13), 174-181. http://www.ijhssnet.com/journal/i ndex/1114

Nindayani, R. (2018). Pengelolaan TKIT sebagai Usaha Masjid menurut Konsep Mudharabah (Studi Kasus di Masjid Baitusshalihin Gampong Ceurih Kecamatan Ulee Kareng Kota Banda Aceh) [Skripsi, UIN Ar- Raniry Banda Aceh]. http://library.arraniry.ac.id

Nurdin. (2020). Tim Registrasi Cagar Budaya Kota Banda Aceh mengusulkan Bangunan Mesjid Tuha Ulee Kareng sebagai cagar budaya. Balai Pelestarian Cagar Budaya Banda Aceh. https://kebudayaan.kemdikbud.go.i d/bpcbaceh/tim-registrasi-cagarbudaya-kota-banda-acehmengusulkan-bangunan-mesjid- 
tuha-ulee-kareng-sebagai-cagarbudaya/

Omar, M., \& Al-Qudsy, S. H. S. I. (2019). Leadership characters in Malaysian religious-NGOs: An introductory overview. International Conference on Da'wah and Islamic Management. /paper/LEADERSHIP-

CHARACTERS-IN-MALAYSIAN-

RELIGIOUS-NGOs-\%3A-

Omar/c726128a6c230b0b33b44c6 c1f24fb2d450313d0

Sari, L. H., Izziah, \& Meutia, E. (2020). Adaptation of local wisdom in contemporary mosque design for achieving good building physics and earthquake resistance. IOP Conference Series: Materials Science and Engineering, 737, 012021. https://doi.org/10.1088/1757899X/737/1/012021

Susanta, G., Amin, C., Kautsar, R., \& Noorrahmah, N. (2007). Membangun masjid \& mushola: 17 desain dan perkiraan volume pekerjaan. Penebar Swadaya.

\section{Kontribusi Penulis}

Zya Dyena Meutia berkontribusi dalam penyusunan konsep penelitian, metodologi, pengumpulan data dan analisis serta penyusunan draft artikel dan revisi.

Zardan Araby berkontribusi dalam analisis data dan penyusunan draftl artikel 